Sumadi $\cdot$ M. Kadapi $\cdot$ A. Nuraeni $\cdot$ N. Wicaksana $\cdot$ M. Rachmadi $\cdot$ S. Rodiah

\title{
Hasil benih empat kultivar kedelai yang ditanam di dataran medium dan dataran tinggi
}

\author{
Yield of four soybean cultivars that were grown at medium and high \\ land
}

Diterima : 11 Desember 2017/Disetujui : 18 Desember 2017 / Dipublikasikan : 30 Desember 2017

CDepartment of Crop Science, Padjadjaran University

\begin{abstract}
Plant growth and yield affected by interaction between genetic character and environment where plant grown. The objective of experiment to determine which appropriate soybean cultivars grown at medium $( \pm 753 \mathrm{~m}$ above sea level) and high land $( \pm 1200 \mathrm{~m}$ above sea level) during the end of rainy season. The experiment was conducted in April to Juli 2016 at experiment station Faculty of Agriculture Unpad, Jatinangor and farmer field, Cikajang District, Garut. The experiment design by Randomized Block Design used four soybean cultivars Anjasmoro, Argomulyo, Arjasari and Grobogan as treatments and it was replicated in five times. The experiment result showed that as general yield of soybean grown at high land higher than soybean grown at medium land. Yied of Anjasmoro and Arjasari higher than Grobogan and Argomulyo, where planting at medium or high land. Seed weight each cultivar as $16.96 \mathrm{~g}, 14.41 \mathrm{~g}, 8.21 \mathrm{~g}$ dan $7.40 \mathrm{~g}$ plant $^{-1}$ respectively was grown at high land or equal with $2.71,2.31,1.31$ and $1.20 \mathrm{ha}^{-1}$, where was grown at medium land are 1.09, 0.99, 0.67 dan 0.85 ton ha $^{-1}$. Culivar of Anjasmoro and Arjasari were more adaptive than Grobogan and Argomulyo. Although, Grobogan seed size was the biggest than others.
\end{abstract}

Key words : soybean, cultivar, medium land, high land, yield

Sari Pertumbuhan dan hasil suatu tanaman merupakan hasil interaksi antara karakter

\footnotetext{
Dikomunikasikan oleh Agus Wahyudin

Sumadi $^{1} \cdot$ M. Kadapi ${ }^{1} \cdot$ A. Nuraeni ${ }^{1} \cdot$ N. Wicaksana ${ }^{1} \cdot$ M. Rachmadi $^{1}$. S. Rodiah ${ }^{2}$

${ }^{1}$ Dosen Program Studi Agroteknologi Fakultas Pertanian Unpad

2 Alumni Program Studi Agroteknologi Fakultas Pertanian Unpad

Korespondensi : sumadi@unpad.ac.id
}

genetik setiap kultivar dengan lingkungan tumbuhnya. Tujuan penelitian ini adalah menetapkan kultivar kedelai yang paling cocok ditanam pada musim hujan di dataran medium $( \pm 753 \mathrm{~m} \mathrm{dpl})$ dan dataran tinggi $( \pm 1200 \mathrm{~m} \mathrm{dpl})$ - Penelitian merupakan percobaan lapangan dilaksanakan pada April sampai dengan Juli 2016. Percobaan dirancang dalam Rancangan Acak Kelompok sederhana yang menguji kultivar meliputi Anjasmoro, Argomulyo, Arjasari dan Grobogan yang diulang 5 (lima) kali. Hasil percobaan menunjukkan bahwa secara umum potensi hasil kedelai di dataran medium hasilnya lebih tinggi dibandingkan yang ditanam di dataran tinggi. Kultivar Anjasmoro dan Arjasari hasilnya lebih tinggi dibandingkan kultivar Grobogan dan Argomulyo, baik yang ditanam di dataran tinggi maupun dataran medium, masing-masing 16.96 $\mathrm{g}, 14.41 \mathrm{~g}, 8.21 \mathrm{~g}$ dan $7.40 \mathrm{~g}$ yang ditanam di dataran medium atau setara dengan $2.71,2.31$, 1.31 dan $1.20 \mathrm{ha}^{-1}$, sedangkan yang ditanam di dataran tinggi sebesar 1.09, 0.99, 0.67 dan 0.85 ton ha ${ }^{-1}$. Kultivar Anjasmoro dan Arjasari merupakan kultivar kedele yang lebih adaptif dibandingkan kultivar Grobogan dan Argomulyo. Ukuran biji kultivar Grobogan paling besar dibandingkan ketiga kultivar lainnya, tetapi hasilnya paling rendah.

Kata kunci : kedele, kultivar, dataran medium, dataran tinggi, hasil benih

\section{Pendahuluan}

Kedelai (Glycine max (L.) Merr) merupakan komoditas utama pangan penting setelah padi dan jagung. Kedelai merupakan salah satu sumber protein nabati, karena mengandung protein yang cukup tinggi. Biji kedelai varietas 
unggul baru yang berukuran besar kandungan proteinnya berkisar 37-43 \% (Ginting dkk., 2009). Dengan demikian kedelai merupakan bahan baku potensial untuk produk olahan, baik skala kecil maupun untuk keperluan industri pangan dan pakan. Rata-rata kebutuhan kedelai setiap tahun mencapai 2,3 juta ton. Produksi kedelai dalam negeri baru mampu memenuhi kebutuhan sekitar 40-45\%, sehingga kekurangannya harus diimpor ( Balitkabi, 2016).

Penurunan produksi kedelai di Indonesia antara lain disebabkan berkurangnya lahan untuk berusaha tani kedelai serta produktivitas kedelai masih rendah. Rata-rata produktivitas kedelai di tingkat petani yaitu $\pm 1,19 \mathrm{t} \mathrm{Ha}^{-1}$, sedangkan rata-rata potensi hasil kultivar unggul 1,80-2,5 ton per hektar (Kusumowarno, 2015). Saat ini beberapa kultivar unggul baru potensi hasilnya bisa mencapai \pm 3 ton (Balitkabi, 2016). Rendahnya produktivitas antara lain karena adanya gangguan alami selama periode tumbuhnya, baik faktor biotik maupun abiotik.

Gangguan faktor biotik berupa hama dapat terjadi sejak fase awal perkecambahan sampai fase pengisian biji (Sumadi, 2000; Makarim., dkk, 2006). Gangguan abiotik dapat berupa curah hujan dan temperatur yang tinggi mengganggu pertumbuhan tanaman. Curah hujan maupun temperatur yang tinggi berpengaruh terhadap proses fisiologis serta menyebabkan gugur bunga dan tanaman rebah (Sumadi. dkk, 2016)

Produktivitas pertanaman kedelai ditentukan karakter genetik dengan faktor lingkungannya. Potensi hasil suatu tanaman dapat dicapai jika selama periode tumbuhnya tanaman tidak mengalami gangguan faktor biotik dan abiotik. Terutama jika gangguan terjadi pada saat pembentukan polong sampai perkembangan biji (Sumadi, 2000). Temperatur yang terlalu tinggi pada fase reproduktif mengakibatkan penurunan hasil kedelai (Isoda et al., 2010). Dengan demikian untuk mencapai potensi hasil masing-masing kultivar harus memperhatikan tingkat kesesuaian lahan dan iklim serta penerapan teknologi budidayanya. Tingkat kesesuaian lahan bagi kedelai bervariasi mulai dari sangat sesuai (highly suitable) sampai tidak sesuai (not suitable).

Beberapa kultivar unggul berbiji besar yang banyak ditanam para petani di Jawa Barat adalah Anjasmoro, Grobogan, dan Argomulyo ( Komunikasi Pribadi dengan UPTD Balai Benih
Palawija Provinsi Jawa Barat, 2014) . Masingmasing mempunyai potensi hasil rata-rata 2.25 ton, 3.44 ton, dan 2.0 ton $\mathrm{Ha}^{-1}$ dengan bobot 100 butir masing-masing 14.8-15.3 g, $18 \mathrm{~g}$ dan $16 \mathrm{~g}$ (Balitkabi, 2016). Hasil penelitian tingkat preferensi petani Jawa Barat terhadap varietas kedelai disimpulkan bahwa $57 \%$ petani Jawa Barat memilih kultivar Anjasmoro (Krisdiana, 2015). Kultivar unggul potensial yang memiliki biji besar, bulat dan warna biji kuning hasil Pemulia Tanaman Fakultas Pertanian Unpad yaitu kultivar Arjasari yang mempunyai potensi hasil 4,68 ton dan bobot 100 butir rata-rata $19,2 \mathrm{~g}$.

\section{Bahan dan Metode}

Penelitian merupakan dua percobaan lapangan yang dilaksanakan di lahan kebun percobaan Fakultas Pertanian Universitas Padjadjaran, Jatinangor, Jawa Barat, dengan ketinggian \pm 700 $\mathrm{m}$ dpl dan di kebun petani Cikajang, Garut dengan ketinggian $\pm 1280 \mathrm{~m} \mathrm{dpl}$. Percobaan dilaksanakan pada April 2016 - Agustus 2016. Pengujian kualitas benih dan penghitungan hasil di Laboratorium Teknologi Benih Departeman Budidaya Pertanian Unpad.

Bahan-bahan yang digunakan meliputi benih unggul bermutu tinggi (Daya Berkecambah antara 96.25-100 \%) kedelai kultivar Anjasmoro, Argomulyo Grobogan diperoleh dari UPBS Balitkabi, Malang dan kultivar Arjasari diperoleh dari Laboratorium Pemuliaan Tanaman Departemen Budidaya Pertanian Fakultas Pertanian Unpad. Pupuk Urea, P SP 36, dan $\mathrm{KCl}$, satu paket pestisida (Decis 2,5 EC, Curacron, Greta 500 EC, Dithane), kertas merang, dan kantong plastik trasnparan. Alat-alat yang digunakan meliputi alat-alat pengolahan tanah, sprayer gendong, timbangan elektrik, oven elektrik, germinator, dan alat pengepres kertas.

Percobaan dirancang dengan Rancangan Acak Kelompok (RAK) sederhana yang menguji empat kultivar kedelai berbiji besar yang sudah direkomendasikan untuk dikembangkan di sentra produksi kedelai Jawa barat yaitu Anjasmoro, Argomulyo, Arjasari dan Grobogan. Semua perlakuan diulang 5 (lima) kali, sehingga masing-masing terdapat 20 petak percobaan. Ukuran petak percobaan $3 \mathrm{~m} \times 1.25 \mathrm{~m}$. Jarak tanam masing-masing disamakan yaitu $25 \mathrm{~cm} \mathrm{x}$ $25 \mathrm{~cm}$, sehingga tiap petak percobaan terdapat 90 lubang tanam. Tiap lubang tanam ditanami terdiri dari 2 batang tanaman. 
Variable yang diamati meliputi data penunjang yang terdiri dari tampilan tanaman, umur berbunga, dan umur panen. Data utama untuk dilakukan pengujian statistic meliputi jumlah polong, jumlah biji, bobot 100 butir, dan bobot biji per tanaman. Pengaruh perlakuan diuji dengan uji $\mathrm{F}$ taraf nyata $5 \%$, selanjutnya untuk mengetahui perbedaan antar perlakuan dilakukan uji jarak Duncan.

\section{Hasil dan Pembahasan}

Umur berbunga dan umur panen. Umur berbunga dan umur panen semua kultivar kedelai yang ditanam di dataran medium Jatinangor lebih cepat dibandingkan dengan yang ditanam di dataran tinggi Cikajang, Kabupaten Garut. Secara umum kedelai yang ditanam di ditanam di dataran medium umur berbunga dan umur panen hampir sama dengan deskripsi masing-masing kultivar ( Tabel1). Hal ini diduga ada kaitannya dengan perbedaan suhu harian pada setiap wilayah. Suhu berpengaruh terhadap proses fisiologis yang berdampak pada pembungaan dan umur matang biji ( Farrar dan Gunn, 1996; Egli dan Crafts - Bradner, 1996 ; Sumadi, 2000).

Umur panen kultivar Arjasari dan Arjasari di Cikajang masing-masing 16 dan 17 hari lebih lama dibandingkan yang ditanam di Jatinangor. Hal ini diduga dipengaruhi oleh kondisi suhu yang berbeda diantara kedua daerah tersebut. Suhu rata-rata di daerah Cikajang $\pm 19.5{ }^{\circ} \mathrm{C}$, sedangkan di Jatinangor rata-rata $23.4{ }^{\circ} \mathrm{C}$ sedangkan suhu optimum bagi tanaman kedelai adalah $22-27{ }^{0} \mathrm{C}$.

Jumlah Polong, Bobot 100 butir, Bobot Biji. Secara umum hasil kedelai di daerah Cikajang yang memiliki rata-rata suhu lebih rendah dibandingkan suhu di Jatinangor, hasilnya lebih rendah dibandingkan kedelai yang ditanam di Jatinangor ( Tabel 2). Jumlah polong isi kultivar Anjasmoro yang ditanam di dataran tinggi lebih tinggi dibandingkan ketiga kultivar lain yang diuji, sedangkan apabila ditanam di dataran medium jumlah polong yang dihasilkan satu sama lain tidak berbeda nyata. Jumlah polong isi secara langsung mempengaruhi bobot biji per tanaman. Hasil percobaan Sumadi (2000) menyimpulkan bahwa bobot biji per tanaman dipengaruhi jumlah polong isi sebesar $37.2 \%$, sedangkan bobot 100 butir hanya 13, $7 \%$ mempengaruhi bobot biji per tanaman. Kultivar Anjasmoro yang ditanam di dataran tinggi maupun dataran medium menghasilkan bobot biji lebih tinggi dibandingkan kultivar Argomulyo dan Grobogan. Kultivar Grobogan jika ditanam di dataran tinggi hasilnya paling rendah, walaupun ukuran

Tabel 1. Perbedaan Rata-rata Umur Berbunga dan Umur Panen Empat Kultivar Kedelai yang Ditanam di Cikajang dan Jatinangor.

\begin{tabular}{|c|c|c|c|c|c|c|c|c|}
\hline \multirow[b]{2}{*}{ Varietas } & \multicolumn{2}{|c|}{ Umur berbunga (hst) } & \multirow[b]{2}{*}{$\begin{array}{c}\text { Selisih } \\
\text { (hari) }\end{array}$} & \multicolumn{2}{|c|}{ Umur Panen (hst) } & \multirow[b]{2}{*}{$\begin{array}{l}\text { Selisih } \\
\text { (hari) }\end{array}$} & \multicolumn{2}{|l|}{ Deskripsi } \\
\hline & JTN & $\mathrm{CKJ}$ & & JTN & $\mathrm{CKJ}$ & & $\begin{array}{l}\text { Berbunga } \\
\text { (hst) }\end{array}$ & $\begin{array}{l}\text { Panen } \\
\text { (hst) }\end{array}$ \\
\hline Anjasmoro & 37 & 46 & 9 & 86 & 103 & 17 & $35,7-39,4$ & $82,5-92,5$ \\
\hline Argomulyo & 34 & 46 & 12 & 80 & 93 & 13 & \pm 35 & $80-82$ \\
\hline Arjasari & 38 & 45 & 7 & 86 & 104 & 18 & $43-46$ & $98-100$ \\
\hline Grobogan & 31 & 44 & 13 & 80 & 96 & 16 & $30-32$ & \pm 76 \\
\hline
\end{tabular}

Keterangan : JTN = Jatinangor $( \pm 700 \mathrm{~m} \mathrm{dpl}), \mathrm{CKJ}=$ Cikajang Garut $( \pm 1280 \mathrm{~m} \mathrm{dpl})$

Tabel 2. Rata-rata Jumlah Polong Isi, Bobot 100 Butir, Bobot Biji Per Tanaman , Bobot Biji Per Ha Empat Kultivar Kedelai yang Ditanam di Dataran Tinggi dan Dataran Medium.

\begin{tabular}{|c|c|c|c|c|c|c|c|c|c|}
\hline \multirow[t]{2}{*}{ KULTIVAR } & \multicolumn{2}{|c|}{ Polong isi (buah) } & \multicolumn{2}{|c|}{ Bobot 100 butir (g) } & \multicolumn{2}{|c|}{$\begin{array}{l}\text { Bobot Biji per } \\
\text { tanaman }(\mathrm{g})\end{array}$} & \multicolumn{3}{|c|}{ Bobot Biji per $\mathrm{Ha}$} \\
\hline & $\overline{\mathrm{CKJ}}$ & JTN & $\mathrm{CKJ}$ & JTN & $\mathrm{CKJ}$ & JTN & CKJ & JTN & Potensi ha ${ }^{-1}$ \\
\hline Anjasmoro & $27.40 \mathrm{c}$ & $41.00 \mathrm{a}$ & $16.13 \mathrm{a}$ & $14.45 \mathrm{a}$ & $8.55 \mathrm{c}$ & $16.96 \mathrm{~b}$ & 1.10 & 2.71 & $2,03-2,25$ * \\
\hline Arjasari & $22.00 \mathrm{~b}$ & $39.96 \mathrm{a}$ & $16.98 \mathrm{a}$ & $15.58 \mathrm{a}$ & $7.79 \mathrm{bc}$ & $14.41 \mathrm{~b}$ & 0.99 & 2.31 & $1-4$ \\
\hline Argomulyo & $18.70 \mathrm{~b}$ & $33.08 \mathrm{a}$ & $15.42 \mathrm{a}$ & $15.90 \mathrm{a}$ & $6.68 \mathrm{~b}$ & $7.40 \mathrm{a}$ & 0.85 & 1.31 & $1,5-2.0^{*}$ \\
\hline Grobogan & $14.30 \mathrm{a}$ & $30.32 \mathrm{a}$ & $22.17 \mathrm{~b}$ & $21.44 \mathrm{~b}$ & $5.24 \mathrm{a}$ & $8.21 \mathrm{a}$ & 0.67 & 1.20 & $2,7-3,4^{*}$ \\
\hline
\end{tabular}

Keterangan : : Nilai rata-rata yang diikuti huruf yang sama pada kolom yang sama tidak berbeda nyata menurut Uji Jarak Duncan pada taraf nyata 5\%. CKJ = Cikajang, JTN = Jatinangor. ${ }^{*}$ infomasi Balitkabi (2016) 
bijinya paling besar dibandingkan kultivar lainnya. Bahkan yang ditanam di dataran medium pun hasil kedelai kultivar Grobogan 55.5-64.7 \% lebih rendah dibandingkan potensi hasilnya.

Kultivar Anjasmoro yang ditanam di dataran medium hasil bijinya $\pm 20,4 \%$ lebih tinggi dibandingkan potensi hasilnya, sedangkan yang ditanam di Cikajang $\pm 51,1 \%$ lebih rendah dibandingkan potensi hasilnya. Kultivar Anjasmoro merupakan salah satu yang direkomendasikan dikembangkan di daerah Sumedang (Hastini, dkk., 2016). Kultivar Arjasari yang ditanam di daerah dataran medium lebih tinggi dari rata-rata potensi hasilnya. Rendahnya hasil biji kedelai yang ditanam di dataran tinggi erat kaitannya dengan proses pengisian biji yang dipengaruhi temperatur (Farrar dan Gunn, 1996; Egli dan CraftsBradner, 1996; Morgan, dkk., 2003). Dengan demikian kultivar Anjasmoro dan Arjasari potensial untuk dikembangkan di daerah dataran medium, tetapi tidak direkomendasikan dikembangkan di dataran tinggi.

\section{Kesimpulan}

Berdasarkan uraian sebelumnya dapat disimpulkan bahwa kondisi iklim suatu wilayah berpengaruh terhadap umur panen dan hasil tanaman. Tanaman kedelai yang ditanam di dataran medium umur panen lebih cepat dibandingkan dengan kedelai yang ditanam di dataran tinggi. Kultivar Anjasmoro dan Arjasari yang ditanam di dataran medium maupun datarn tinggi hasilnya lebih tinggi dibandingkan kultivar Argomulyo dan Grobogan. Ukuran biji kultivar Grobogan paling tinggi dibandingkan dengan ketiga kultivar lainnya, tetapi hasil biji per tanaman paling rendah dibandingkan lainnya.

\section{Ucapan terimakasih}

Pada kesempatan ini kami mengucapkan terimakasih kepada pemerintah provinsi Jawa Barat melalui BP3IPTEK yang menginisiasi dilaksanakanya penelitian ini.

\section{Daftar Pustaka}

Adisarwanto, T., Subandi, dan Sudaryono, 2013. Teknologi Produksi Kedelai. Sumarno, S.
Adi., W.Hermanto dan H. Kasim (Ed.). Kedelai. Teknik Produksi dan Pengembangan. Pusat Penelitian dan Pengembangan Tanaman Pangan Badan Penelitian dan Pengembangan Pertanian. Bogor. 229252.

Balitkabi, 2016. Deskripsi Varietas Unggul Kedelai 1918-2016. Balai Penelitian Tanaman Aneka Kacang dan Umbi. Malang.

Egli, D.B and S.J. Craft-Bradner. 1996. Soybean. In. E. Zamski and A.A. Schaffer (ed.). Photoassimilate Distribution in Plant and Crops. Source - Sink Relationships. Marcel Dekker. Inc. New York. Basel. Hongkong.

Farrar, J.F. and S. Gunn. 1996. Effect of temperature and Atmospheric $\mathrm{CO}_{2}$ on Source - Sink Relations in the context of climate change. In. E. Zamski and A.A. Schaffer (ed.). Photoassimilate Distribution in Plant and Crops. Source - Sink Relationships. Marcel Dekker. Inc. New York. Basel. Hongkong.

Ginting, E. ,S. S. Antarlina, dan S. Widowati. 2009. Varietas unggul kedelai untuk bahan baku industry pangan. Jurnal Litbang Pertanian, 28(3): $79-87$

Hastini, T.,S. L. Mulijanti, dan N. Sunandar. 2016. Potensi Hasil Enam Varietas Unggul Kedelai di Kabupaten Sumedang. Pros. Seminar Nasional Hasil Penelitian Tanaman Aneka Kacang dan Umbi Tahun 2015. Peran Inovasi Teknologi Aneka Kacang dan Umbi dalam Mendukung Program Kedaulatan Pangan. Malang 19 Mei 2016.

Isoda, A., H. Mao, Z. Li and P. Wang, (2010) Growth of High-Yielding Soybeans and its Relation to Air Temperature in Xinjiang, China, Plant Production Sci. 13:2, 209-217.

Krisdiana, R. 2015. Faktor-faktor yang menentukan pengambilan keputusan petani dalam memilih varietas unggul kedelai : Kasus Jawa Barat. Prosiding Seminar Hasil Penelitian Tanaman Aneka Kacang dan Umbi 2014. 491 - 497.

Kusumowarno, S. 2015. Peluang Peningkatan Produksi Kedelai Lahan Kering Mendukung Kemandirian Pangan. Prosiding Seminar Hasil Penelitian Tanaman Aneka Kacang dan Umbi 2014. Bogori. 337 - 342.

Makarim, A.K., D.M. Arsyad dan A. Ghozi. 2006. Model simulasi peningkatan produksi kedelai di lahan suboptimal. Prosiding Lokakarya Pengembangan Kedelai di Lahan Sub-Optimal. Malang. 19 - 36 
Morgan, P.B., E.A. Ainsworth, and S.P. Long. 2003. How does elevated ozone impact soybean? A meta-analysis of photosynthesis, growth and Yield. Plant, Cell and Environment ( 26) : 1317-1328.

Sumadi, 2000. Tanggapan kedelai yang tercekam kekeringan selama periode pembentukan polong sampai perkembangan biji terhadap aplikasi sitokinin dan giberelin. Disertasi Program Pascasarjana Universitas Padjadjaran. Bandung. ( Tidak dipublikasi). Sumadi, M. Rachmadi dan E. Suminar. 2016. Respons benih kedelai terdeteriorasi terhadap aplikasi pelapian benih. Prosiding Seminar Nasional dan Kongres PERAGI. Bogor. 653 - 661 . 